\title{
Growing and finishing performance and body composition for St. Croix wethers consuming growing diets differing in grain and protein levels*
}

\author{
A. L. Goetsch \\ Dale Bumpers Small Farms Research Center, USDA, ARS \\ 6883 South State Highway 23, Booneville, Arkansas 72927-9214, USA
}

(Received 6 June 1997; accepted 19 August 1997)

\begin{abstract}
Twenty-four 3 -month-old St. Croix wethers $(14.5 \pm 0.53 \mathrm{~kg}$ initial live weight $)$ were used to determine potential for enhancing efficiency of feed utilization by feeding a growing dict marginal in protein ( 83 days) to elevate fat deposition and partially delay protein accretion until a subsequent finishing phase ( 65 days; $80 \%$ concentrate. $20 \%$ crude protein diet). Endophyte-frec fescue hay ( $14.4 \%$ crude protein) was consumed ad libitum during growing ( 83 days), with $1.25 \%$ body weight of maize plus a mixture of high-protein feedstuffs ( $82 \%$ crude protein) (LM-P), $2.5 \%$ body weight of maize plus high-protein feedstuffs (HM-P), or $2.5 \%$ body weight of maize (HM). Growing phase dry matter intake was similar among treatments $(923,978$, and $900 \mathrm{~g} /$ day; SE 64.1) and live weight gain was greater $(P<0.05)$ for HM-P vs LM-P and HM $(139,188$, and $148 \mathrm{~g} /$ day for LM-P, HM-P, and HM, respectively; SE 8.9). Empty body protein mass after growing ranked $(\mathrm{P}<0.05)$ $\mathrm{HM}<\mathrm{LM}-\mathrm{P}<\mathrm{HM}-\mathrm{P}(4.17,4.31$, and $4.10 \mathrm{~kg}$; SE 0.011$)$, and fat mass was greater $(\mathrm{P}<0.05)$ for HM-P vs LM-P and HM (6.07, 7.01, and 5.66 kg for LM-P, IM-P, and IIM, respectively; SE 0.188). Dry matter intake and live weight gain during, and body composition after, finishing were similar among treatments, although much of the difference in fat mass after growing between HM-P and other treatments was maintained through finishing $(13.6,14.2$, and $13.6 \mathrm{~kg}$ for LM-P, HM-P, and HM, respectively; SE 0.80 ).
\end{abstract}

KEY WORDS: lambs, live weight gains, feed utilization, body composition

* Mention of a trademark or proprictary product in this paper does not constitute a guarantee or warranty of the product by the USDA or the ARS and does not imply its approval to the exclusion of other products that may be suitable. 


\section{INTRODUCTION}

Conventional growing-finishing ruminant production systems entail either accelerated programs in which weaned animals, often at a relatively high live weight, consume high concentrate diets until slaughter, or consumption after weaning of forage-based diets preceding concentrate diets. With the first system, the dietary protein level normally is adequate throughout the growing-finishing period for lean tissue deposition near genetic potential, resulting in maximal potential accretion early in the period and a slow decline thereafter. Fat deposition increases steadily as the feeding period progresses, with fat contributing most energy gained late. The second system is fairly similar in regards to temporal patterns of protein and fat accretion; however, patterns are more biphasic primarily because of limited energy absorption during the initial growing, forage-based diet phase. Thus, with limited fat deposition and perhaps a slight to moderate restriction of protein accretion during this phase, in the latter phase with a high concentrate diet fat constitutes a relatively greater proportion of deposited tissue than with the first type of conventional system. Although growth involves coordinated changes in deposition of fat, protein, and ash, rather than being a completely segmented process, in both systems but perhaps to differing degrees protein is deposited primarily in the first phase of the feeding period and fat accumulates in the second.

In terms of maximizing efficiency of energy and nitrogen use, conventional systems for growing-finishing ruminants might be viewed as being somewhat poorly designed. In regards to nitrogen, dietary protein concentration must be moderate to high throughout the first segment of these systems to support high protein accretion. This is also true for the latter segment, but for support of microbial fermentation sufficient for production of digestion end products (primarily volatile fatty acids) necessary for high fat accretion. Relating to efficiencies of metabolism of both energy and nitrogen, proportionally greatest protein accretion early in conventional growing-finishing systems results in considerable time during which proteinaccous tissues must be maintained, even during latter periods when little or no accretion occurs. Conversely, adipose is maintained for little time relative to proteinaceous tissue.

Efficiency of energy use is much greater for accretion of fat than protein. For example, Owens et al. (1995) stated efficiencies of 47 and $76 \%$ for accretion of protein and fat, respectively. This difference occurs largely because proteinaceous tissues turn over more rapidly than adipose (Owens et al., 1995). Although more controversial, the energetic cost of maintaining adipose tissue appears low compared with that of protein (Webster, 1981). The rate of whole body protein turnover and fractional synthesis rate of muscle protein decrease as animals mature; however, typical changes with increasing age during growing-finishing 
seem small relative to the difference in efficiency between fat and protein accretion, and the ratio of protein accretion or synthesis to degradation decreases with increasing age (Lobley, 1994). Also, protein turnover, occurring with only tissue maintenance or with accretion, is accompanied by amino acid consumption and subsequent nitrogen excretion (Lobley, 1994).

Based on the aforementioned discussion, it seems logical that efficiencies of energy and nitrogen metabolism in ruminant growing-finishing systems would be enhanced if temporal patterns of protein and fat accretion were altered to minimize the time during which proteinaceous tissues must be maintained. This might be achieved by use of a low or marginal dietary protein level in the early phase of the growing-finishing period to limit protein accretion, which could concomitantly elevate the proportion of fat in deposited tissue (Ørskov et al., 1976). Likewise, a low dietary nitrogen level during this phase should increase retention and decrease excretion of nitrogen compared with conventional systems. In the latter part of the growing-finishing period, high dietary levels of total and ruminally undegradable protein, coupled with the earlier restriction of protein deposition, should promote maximum accretion of protein. In addition, delayed usage of a growth promotant (e.g., zeranol) until the latter phase with a high protein diet would contribute to maximal protein accretion near slaughter time. Such a system could minimize the time of, and energy use in, maintenance of proteinaceous tissue. Therefore, the general objective of this experiment was to assess the potential for altering temporal patterns of protein and fat accretion in growing-finishing ruminants to increase efficiency of feed utilization and energy metabolism. More specifically, objectives were to determine effects of different dietary levels of protein and cereal grain on feed intake, live weight gain, feed efficiency, and body composition during growing and a subsequent finishing phase in St. Croix wether lambs.

\section{MATERIAL AND METHODS}

\section{Animals}

Twenty-four St. Croix wether lambs were used in a 148-day performance experiment. Wethers were born in mid-June, 1996 and weaned at approximately 2 months of age $(11.8 \pm 0.50 \mathrm{~kg}$ body weight) in mid-August. Vaccination for Clostridium organisms (Clostridium chauvoei, septicum, novvi Type B, haemolyticum, tetani and perfringens Types C and D) and treatment with Ivomec ${ }^{k}$ (Merck and Co., Rahway, NJ) occurred at weaning; wethers were again treated with Ivomec $^{k}$ at the beginning of the experiment. The experiment began 3 weeks after 
weaning, with a mean body weight (BW) of $14.5 \pm 0.53 \mathrm{~kg}$. Wethers were allotted to three treatments for similar mean $\mathrm{BW}$ and variation in $\mathrm{BW}$, then randomly assigned within treatments to pens (concrete; $3-\mathrm{x} 12.2-\mathrm{m}$; two pens per treatment and four wethers per pen).

\section{Diets}

The experiment consisted of an 83-day growing phase followed by a 65 -day finishing phase. During the growing phase, coarsely ground $(1.9-\mathrm{cm}$ screen) endophyte-free fescue hay (Festuca arundinacea, L.; Table 1) was consumed ad libitum, with equal quantities dispensed in feeders at 7 and $16 \mathrm{~h}$. Hay refusals were collected and weighed before the morning meal. Concentrates were fed at $7 \mathrm{~h}$, being top-dressed on hay. The treatment designated as LM-P consisted of $0.3 \% \mathrm{BW}$ (DM basis) of soyabean meal, $0.2 \% \mathrm{BW}$ of a mixture of feedstuffs high in ruminally undegradable protein (RUP), and $1.25 \% \mathrm{BW}$ of ground maize (Table 1). The RUP supplement consisted of $35.9 \%$ fish meal, $27.5 \%$ feather meal, and $36.6 \%$ blood meal. The HM-P treatment entailed the same levels of soyabean meal and RUP, but with $2.5 \%$ BW of maize. Lastly, the HM treatment included feeding $2.5 \% \mathrm{BW}$ of maize without soyabean meal or RUP. Feeding rates were based on initial $\mathrm{BW}$ and $\mathrm{BW}$ after 21,43 , and 64 days, and on predicted BW between weighings. On days 1 to 21,22 to 43 , and 44 to $64,8,10.5$, and $12.8 \mathrm{~g} /$ day of a mineral mixture (contained at least, $\%: \mathrm{Ca} 12.5, \mathrm{P} 12, \mathrm{NaCl}$ 18, $\mathrm{Zn} \mathrm{0.8,} \mathrm{Fe} \mathrm{0.7,} \mathrm{Mn} \mathrm{0.5,} \mathrm{I} \mathrm{0.02,} \mathrm{Co} \mathrm{0.005,} \mathrm{Se} \mathrm{0.00015,} \mathrm{and} 2.2$ million IU

TABLE 1

Fecdstuff composition

\begin{tabular}{|c|c|c|c|c|c|}
\hline \multirow[b]{2}{*}{ Item } & \multicolumn{5}{|c|}{ Growing phase } \\
\hline & $\begin{array}{c}\text { Soyabean } \\
\text { meal }\end{array}$ & $\begin{array}{c}\text { Ruminally } \\
\text { undegradable } \\
\text { protein }\end{array}$ & $\begin{array}{l}\text { Ground } \\
\text { maize }\end{array}$ & $\begin{array}{l}\text { Endophyte-free } \\
\text { fescue hay }\end{array}$ & $\begin{array}{c}\text { Finishing } \\
\text { phase } \\
80 \% \text { concentrate } \\
\text { diet }\end{array}$ \\
\hline \multicolumn{6}{|c|}{$\%$ of dry matter } \\
\hline Crude protein & 55.4 & 81.9 & 9.1 & 14.4 & 20.3 \\
\hline $\begin{array}{l}\text { Neutral detergent } \\
\text { fibre }\end{array}$ & & & & 61.5 & \\
\hline \multicolumn{6}{|l|}{ Acid detergent } \\
\hline fibre & & & & 31.6 & \\
\hline \multicolumn{6}{|l|}{ Acid detergent } \\
\hline lignin & & & & 4.2 & \\
\hline Cellulose & & & & 27.1 & \\
\hline Hemicellulose & & & & 29.9 & \\
\hline
\end{tabular}


vitamin $\mathrm{A} / \mathrm{kg}$, and $275 \mathrm{IU}$ vitamin $\mathrm{E} / \mathrm{kg}$; air-dry basis) was thoroughly mixed with concentrates.

A Ralgro ${ }^{\mathrm{H}}$ implant (Mallinckrodt Veterinary, Mundelein, IL; $12 \mathrm{mg}$ zeranol) and Ivomec $^{\mathrm{R}}$ were administered at the beginning of the finishing phase. The 65 -day finishing phase entailed ad libitum consumption of an $80 \%$ concentrate diet (Tables 1 and 2) offered once daily at $7 \mathrm{~h}$, except during the first week when two meals daily were given $(7$ and $16 \mathrm{~h}$ ). Also during the first week, the dietary level of hay was decreased sequentially to zero from that previously during the growing phase. Body weight (unshrunk) was determined after 21,43 , and 65 days.

\section{Measures}

After full weights were determined at the end of growing and finishing phases, wethers were shrunk $(24 \mathrm{~h})$ to estimate body composition via urea dilution, as described by Galloway et al. (1996). To determine energy accretion during finishing, 5.52 and $9.4 \mathrm{kcal} / \mathrm{g}$ of protein and fat, respectively, were assumed (ARC, 1980).

Feedstuffs were sampled daily to form weekly composites. Hay was ground to pass a $1-\mathrm{mm}$ screen and analyzed for dry matter (DM), Kjeldahl nitrogen (AOAC, 1984), neutral detergent fibre, acid detergent fibre, and acid detergent lignin (filter bag technique; ANKOM Technology Corp., Fairport. NY). Cellulose was determined as loss in weight upon sulphuric acid treatment and

TABLE: 2

Finishing diel composition

\begin{tabular}{lc}
\hline Ingredient & $\%$ of dry matter \\
\hline Ground maize & 64.073 \\
Cottonseed hulls & 10.000 \\
Dehydrated lucerne pelicts & 10.000 \\
Soyabean meal & 4.400 \\
Fish meal & 2.750 \\
Soyabean oil & 2.500 \\
Molasses & 2.500 \\
Blood meal & 2.200 \\
Calcium carbonate & 0.800 \\
Urea & 0.500 \\
Sodium chloride & 0.180 \\
Trace mineral premix & \\
Vitamin premix" & 0.050 \\
Bovatec & 68 \\
\hline
\end{tabular}

${ }^{a}$ contained at least, \%: Zn 12, Fe 10, Mn 8, Cu 1.5, I 0.3, Co 0.1, and Se 0.02 (air-dry basis)

${ }^{b}$ contained at least 8.8 million IU of vitamin $A, 1.8$ million IU of vitamin $D_{3}$, and 1.100 IU of vitamin E per $\mathrm{kg}$ (air-dry basis) 
hemicellulose as the difference between neutral and acid detergent fibre concentrations. Concentrate feedstuffs were analyzed for nitrogen.

\section{Statistical analyses}

Data were analyzed by General Linear Models procedures of SAS (1990). The model for BW gain and body composition consisted of treatment and pen within treatment, with the latter term used as the error to test the effect of the former. Feed intake data were analyzed with treatment in the model, and performance measures were averaged by pen to estimate variables such as feed efficiency. Differences among treatments were determined by least significant difference procedures when the treatment $F$-test was significant $(P<0.07)$. Missing body composition data (after growing and finishing) resulted from of an unknown problem that caused unreasonable values after growing for two wethers.

\section{RESULTS}

Feedstuffs were generally as expected in concentrations of chemical constituents (Table 1). As designed, crude protein supplied by soyabean meal and RUP during growing was similar. The dietary concentration of crude protein during growing was $19.1,17.4$, and $11.2 \%$ for LM-P, HM-P, and HM, respectively.

Hay intake during growing was greater $(\mathrm{P}<0.05)$ for $\mathrm{LM}-\mathrm{P}$ than for HM-P and HM; thus, total DM intake was similar among treatments (Table 3). Based on feedstuff nitrogen analysis and tabular metabolizable energy concentrations (NRC, 1984: feather meal; NRC, 1985), during the growing phase crude protein intake was 176,170 , and $101 \mathrm{~g} / \mathrm{day}$, and metabolizable energy intake was 2.36 , 2.75 , and $2.49 \mathrm{Mcal} /$ day for LM-P, HM-P. and HM, respectively.

Growing live weight gain (Table 3 ) was greater $(\mathrm{P}<0.05)$ for HM-P vs LM-P and $\mathrm{HM}$ and tended $(\mathrm{P}=0.10)$ to be greater for HM than for LM-P. Consequently, the ratio of live weight gain to DM intake during growing was greatest $(P<0.05)$ among treatments for HM-P. There were no differences among treatments in DM intake, live weight gain, or the ratio of live weight gain to DM intake during the finishing phase or for the total experiment (growing plus finishing phases). However, numerical differences among treatments in finishing live weight gain and the ratio of live weight gain to DM intake largely compensated for opposite differences in the growing phase.

Empty body weight at the end of the growing phase in the present experiment ranked $(\mathrm{P}<0.05) \mathrm{HM}<\mathrm{LM}-\mathrm{P}<\mathrm{HM}-\mathrm{P}$, with a greater difference between HM-P and LM-P than between LM-P and HM (Table 4). Similar findings were 
TABLE 3

Feed intake, live weight gain, and feed efficiency of wethers consuming different growing diets and during finishing

\begin{tabular}{|c|c|c|c|c|c|}
\hline \multirow{2}{*}{ Phase } & \multirow{2}{*}{ Variable } & \multicolumn{3}{|c|}{ Treatment ${ }^{a}$} & \multirow[b]{2}{*}{ SE } \\
\hline & & LM-P & HM-P & HM & \\
\hline \multirow[t]{9}{*}{ Growing, 83 days } & Dry matter intake, g/day: & & & & \\
\hline & Soyabean meal & 67 & 67 & & \\
\hline & Ruminally undegradable & & & & \\
\hline & protein supplement & 45 & 45 & & \\
\hline & Ground maize & 275 & 549 & 549 & \\
\hline & Endophyte-free fescue hay & 536 & 317 & 351 & 64.1 \\
\hline & Total & 923 & 978 & 900 & 64.1 \\
\hline & Live weight gain, g/day & $139^{c}$ & $188^{\mathrm{d}}$ & $148^{\circ}$ & 8.9 \\
\hline & $\begin{array}{l}\text { Live weight gain:dry matter } \\
\text { intake }\end{array}$ & $0.150^{\circ}$ & $0.192^{\mathrm{d}}$ & $0.164^{\circ}$ & 0.0034 \\
\hline \multirow[t]{3}{*}{ Finishing, 65 days } & Dry matter intake, g/day ${ }^{\mathrm{b}}$ & 1.148 & 1.208 & 1.208 & 66.7 \\
\hline & Live weight gain. g/day & 222 & 201 & 238 & 18.5 \\
\hline & $\begin{array}{l}\text { Live weight gain:dry matter } \\
\text { intake }\end{array}$ & 0.193 & 0.166 & 0.197 & 0.0084 \\
\hline \multirow[t]{3}{*}{ Total experiment. 148 days } & Dry matter intake, g/day & 1.022 & 1.079 & 1.035 & 64.6 \\
\hline & Live weight gain, g/day & 175 & 193 & 187 & 12.5 \\
\hline & $\begin{array}{l}\text { Live weight gain:dry matter } \\
\text { intake }\end{array}$ & 0.171 & 0.179 & 0.181 & 0.0026 \\
\hline
\end{tabular}

"LM-P = growing supplementation with soyabean meal, a ruminally undegradable protein source mixture, and $1.25 \%$ body weight of maize

HM-P = growing suppicmentation with soyabean meal, a ruminally undegradable protein source mixture, and $2.5 \%$ body weight of maize

$\mathrm{HM}=$ growing supplementation with $2.5 \%$ body weight (DM basis) of maizc

${ }^{b}$ includes an $80 \%$ concentrate diet and an average of $15 \mathrm{~g} /$ day of endophyte-free fescuc hay used for adjustment to the concentrate diet

c. means in a row without a common supercript differ at $\mathrm{P}<0.05$

observed for $\mathrm{kg}$ of water, fat, protein, and ash, although the difference in fat mass between LM-P and HM was not significant. Percentages of water, protein, and ash in the empty body were lower for HM-P than for LM-P $(\mathrm{P}=0.06)$ and HM $(\mathrm{P}<0.05)$. Likewise, the percentage of fat was greater for HM-P vs LM-P $(\mathrm{P}=0.08)$ and $\mathrm{HM}(\mathrm{P}<0.05)$.

No treatment differences were observed in mass of body components in $\mathrm{kg}$ or as percentages of empty body weight after the finishing phase, and no differences occurred in accretion during finishing of protein, fat, or energy. However, numerically much of the difference between HM-P and other treatments in fat after the growing phase was maintained throughout finishing. 
TABLE 4

Body composition after growing and finishing and accretion during finishing for wethers consuming different growing diets and during finishing

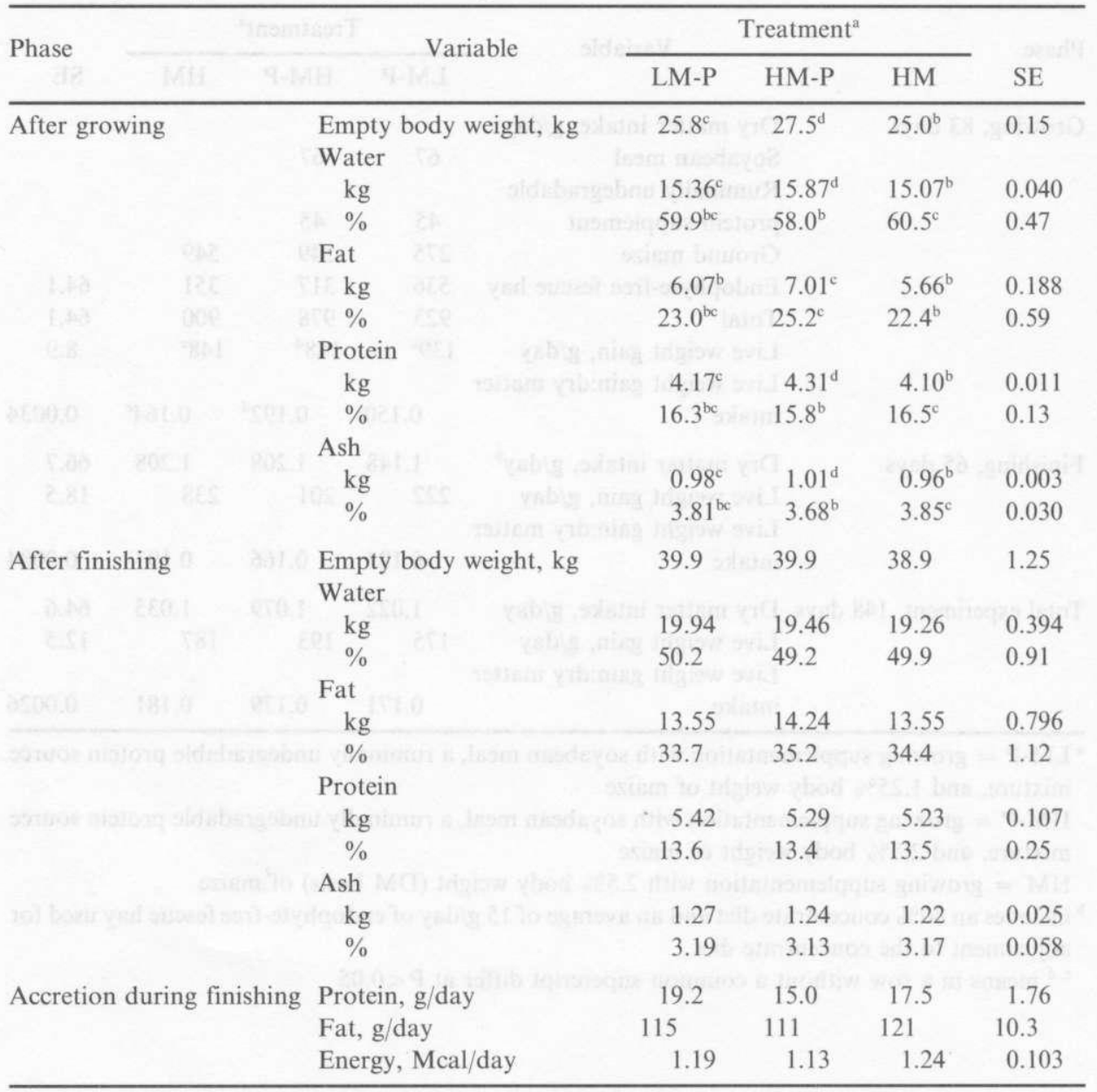

${ }^{\mathrm{a}} \mathrm{LM}-\mathrm{P}=$ growing supplementation with soyabean meal, a ruminally undegradable protein source mixture, and $1.25 \%$ body weight of maize; HM-P = growing supplementation with soyabean meal, a ruminally undegradable protein source mixture, and $2.5 \%$ body weight of maize; $\mathrm{HM}=$ growing supplementation with $2.5 \%$ body weight (DM basis) of maize a, b, d means in a row without a common supercript differ at $\mathrm{P}<0.05$ 


\section{DISCUSSION}

\section{Assumptions}

Factors most limiting to performance for each treatment cannot be conclusively discerned from these data, although projections based on dietary composition and nutrient intakes are possible. Feed intake and its control obviously influenced performance. Hence, to discuss factors limiting performance, it was assumed that feed intake was controlled metabolically or physiologically (Ketelaars and Tolkamp, 1992) rather than through physical means (i.e., gut digesta fill). Similarly, it was assumed that because feed intake was ad libitum, efficiency of whole body energy metabolism (i.e., heat increment relative to metabolizable energy intake) was constant (Tolkamp and Ketelaars, 1994). Relatedly, heat production by the gut and liver accounts for a considerable proportion of that by the whole body (Ferrell, 1988), and with ad libitum consumption splanchnic bed heat production relative to metabolizable energy intake decreases as dietary concentrate level increases (Goetsch and Patil, 1997).

\section{$L M-P$ and $H M-P$ treatments}

For LM-P wethers, it is most likely that energy available to, or used by, peripheral tissues was most limiting to live weight gain during growing, which is in part attributable to lowest metabolizable energy intake. In addition, because dietary forage concentration was greatest for LM-P, energy consumed by splanchnic tissues as a proportion of metabolizable energy intake and the contribution of splanchnic tissues to whole body heat production may have been greatest. Correspondingly, the proportion of absorbed energy used by peripheral tissues was probably less for LM-P vs HM-P. In addition, highest amino acid absorption relative to energy availability in the periphery for LM-P should have elicited high energy use by the liver in urea synthesis (Reynolds, 1992).

Quantities of amino acids and energy absorbed for HM-P probably aligned most closely among treatments with potential for use in tissue accretion during growing, as implicated by greatest live weight gain during, and fat mass after, growing. Similar rates of live weight gain during growing and finishing phases for HM-P wethers and fairly comparable protein mass among treatments after growing (although differences were significant) imply that protein accretion during growing was near maximal for all treatments. Greater live weight gain during, and fat mass after, the growing phase for HM-P vs LM-P apparently resulted from both greater metabolizable energy intake and the greater proportion of absorbed energy available to peripheral tissues. Other factors that may have promoted greater fat accretion during growing for HM-P vs LM-P 
include differences in the array of absorbed metabolites (e.g., propionate, glucose) due to dietary maize level that influenced efficiency of metabolite (e.g., acetate) use in lipogenesis and, thus, impacted feed intake (MacRae and Lobley, 1982; Ketelaars and Tolkamp, 1992).

That much of the difference in fat mass between HM-P and other treatments present after growing was maintained through finishing agrees with results of Galloway et al. (1996). Because live weight gain and gain:feed during finishing were similar among treatments, it would appear that enhancement or occurrence of relatively high fat deposition during the growing phase does not negatively affect subsequent finishing performance, perhaps because of little energy required for adipose maintenance.

\section{HM treatment}

Studies regarding alterations of body composition of growing-finishing ruminants independent of rate of live weight gain occurred 20 to 25 years earlier, with little research directly related to the present experiment in the recent past. Ørskov et al. (1971) fed early weaned male and female lambs concentrate diets with 11,16 , or $19 \%$ crude protein. The $11 \%$ protein diet resulted in lowest DM intake and least efficient feed conversion up to slaughter weight, which in part was because of increased fat concentration in accreted tissue, particularly at 25 to $30 \mathrm{~kg}$ of live weight. The magnitude of differences in body composition diminished as live weight increased further, but differences still were apparent at $50 \mathrm{~kg}$. The decreasing effect of dietary protein level on body composition with increasing live weight was attributed to the decreasing potential for protein accretion and increasing capacity for fat deposition by lambs consuming higher crude protein diets and less energy and amino acids used for tissue maintenance with the $11 \%$ protein diet. In a similar experiment, Andrews and Ørskov (1970) fed early weaned female lambs concentrate diets ranging from 10 to $20 \%$ crude protein at three levels of feeding. Results were fairly similar to those noted by Ørksov et al. (1971), in that carcass fat concentration was greater for low vs high dietary protein levels at each feeding level, with effects diminishing as final live weight $(40 \mathrm{~kg})$ was approached.

Ørskov et al. (1976) fed male lambs ad libitum concentrate diets 10 or $20 \%$ crude protein from approximately $15 \mathrm{~kg}$ to $75 \mathrm{~kg}$ live weight. Another treatment entailed switching from 10 to $20 \%$ protein at $28 \mathrm{~kg}$ live weight. Body composition differences between lambs continuously receiving $10 v 20 \%$ protein were similar to those in experiments previously outlined. For the treatment with the dietary change from 10 to $20 \%$ protein, at $28 \mathrm{~kg}$ fat concentration in the empty body was approximately $42 \%$ greater than that for lambs continuously fed the high protein diet, whereas this difference disappeared by $55 \mathrm{~kg}$. Increased 
live weight gain (i.e., 457 vs $353 \mathrm{~g} /$ day at 28 to $35 \mathrm{~kg}$; 396 vs $360 \mathrm{~g} / \mathrm{d}$ from 28 to 55 $\mathrm{kg}$ ) with the diet switch was not attributable to differences in DM intake, since intake for the treatment with the diet change was restricted thereafter to no more than that of lambs continuously fed $20 \%$ protein. The change in diets increased efficiency of feed conversion thereafter compared with the continuous $20 \%$ protein treatment, which was partially attributed to decreased energy use in tissue maintenance. The initial substantial difference in feed efficiency decreased in magnitude with advancing time and live weight, and disappeared at approximately $55 \mathrm{~kg}$.

Growing performance for HM wethers in the present experiment was not supportive of the primary hypothesis of the experiment, regarding potential to shift temporal patterns of protein and fat accretion during growing-finishing. Protein mass after growing was 77,82 and $78 \%$ (SE 1.4) of that after finishing for LM-P, HM-P, and HM treatments, respectively, and values for fat were 44, 50 and $42 \%$ (SE 3.2), respectively. Thus, there appeared considerable potential for the proposed modification.

A number of factors may have prevented expected effects of the HM treatment. First, it is likely that fibre digestion was lower for HM and HM-P than for LM-P because of the difference in maize intake, which would have influenced conditions such as ruminal $\mathrm{pH}$, preferential starch $v s$ fibre degradation by ruminal microbes, and shifts in types of microbes present in the rumen (Ørskov and Ryle, 1992). Furthermore, it is possible that fibre digestibility was slightly lower for HM than for HM-P, if the high level of maize coupled with the marginal dietary crude protein level for the HM treatment resulted in low ruminal concentrations of nitrogenous compounds (e.g., ammonia) that limited microbial fibre digestion. Thus, actual metabolizable energy intakes may have differed from those calculated.

Secondly, the particular type of a nimal used in this experiment could have had substantial impact on the opportunity for shifting temporal patterns of protein and fat accretion. Similar protein mass among treatments at the end of the growing phase suggests a lower dietary protein requirement for these wethers than expected based on NRC (1985). Thus, the dietary concentration of crude protein did not seem limiting to protein deposition. However, these considerations do not explain lower live weight gain during, and fat mass after, growing for HM than for HM-P wethers.

Assuming constant whole body efficiency of energy metabolism among treatments and that fairly similar dietary proportions of forage for HM and HM-P treatments had comparable effects on splanchnic tissue heat production relative to metabolizable energy intake, live weight gain during, and fat mass after, growing should not have differed greatly between HM and HM-P. Differences in these variables can be, however, explained if energy metabolism 
differed between HM and HM-P, with corresponding effects on feed intake. The factor most likely responsible involves protein. Because protein mass after growing was not greatly different among treatments, it is unlikely that effects of amino acid absorption on feed intake were simply via correction of amino acid deficiencies for peripheral protein accretion.

Relatively little protein in forages such as the fescue hay used in this experiment passes to the intestines intact. Moreover, considerable maize protein escapes ruminal degradation, and the profile of amino acids in maize protein is not ideal relative to the array optimal for growing ruminants (Asplund, 1994). Also, efficiency of microbial protein synthesis could have been limited with HM if supplies of nitrogenous compounds in the rumen were limiting. Although measures for substantiation were not made, it is a reasonable possibility that intake by HM wethers during the growing phase was restricted because energy expenditure and heat production associated with an imbalanced array of absorbed amino acids, which would encompass effects on heat production by both peripheral tissues and the liver (Harris and Lobley, 1991).

The discussion presented in the paragraph immediately preceding is in contrast to the primary hypothesis and not in accordance with results of other studies (e.g., Ørskov et al., 1976). Factors most likely involved include a relatively minor limitation in the total quantity of absorbed amino acids relative to potential for amino acid use in protein synthesis. Conversely, Ørskov et al. (1976) used Suffolk cross male lambs that probably possessed much greater potential for protein deposition than the St. Croix wethers used in the present experiment. Also, because diets of Ørskov et al. (1976) were based on barley, for which ruminal protein degradation is more thorough than for maize, an imbalanced array of absorbed amino acids was less likely than in the present experiment. Nonetheless, it is conceivable that appreciable enhancement of the proportion of fat in deposited tissue earlier in a growing-finishing phase might be possible only if the dietary protein restriction is relatively severe and occurs at the expense of a marked depression in early live weight gain, as noted by Ørskov et al. (1976). Severely restricted early growth may not allow fully compensatory protein accretion later or could necessitate a longer feeding period to achieve desired slaughter weights and, thus, might decrease overall efficiency of feed utilization during growing-finishing.

\section{CONCLUSIONS}

Feeding St. Croix wether lambs $2.5 \%$ body weight of maize with $14.4 \%$ crude protein grass hay consumed ad libitum during a growing phase resulted in performance and body composition similar to $1.25 \%$ body weight of maize and 
supplemental protein sources, whereas the high amount of maize plus protein sources elicited greater live weight gain primarily through elevated fat deposition. In the subsequent finishing phase with a $20 \%$ protein, $80 \%$ concentrate diet, performance and final body composition did not differ among treatments, although much of the increase in fat mass for the high level of maize plus protein sources achieved during growing was maintained through finishing. In conclusion, there does not appear potential to enhance early fat deposition and partially delay protein accretion by providing a marginal protein diet with a moderate to high level of dietary maize with St. Croix wethers. Further study seems warranted with animal types possessing greater growth potential and perhaps more limiting dietary protein levels.

\section{ACKNOWLEDGEMENTS}

Appreciation is expressed to J. Cherry, G. Aiken, S. Tabler, D. Jones, G. Robson, K. Chapman, and S. Haller for assistance in feeding, sample, collection, and(or) laboratory analyses.

\section{REFERENCES}

Andrews R.P., Ørskov E.R., 1970. The nutrition of the early weaned lamb. II. The effect of dietary protein concentrations, feed level and sex on body composition at two live weights. J. Agric. Sci., Camb. 75, 19-26

AOAC, 1984. Official Methods of Analysis. 14th Edition. Association of Official Analytical Chemists. Washington, IC

ARC, 1980. The Nutrient Requirements of Ruminant Livestock. Commonwealth Agricultural Burcaux. Farnham Royal, UK

Asplund J.M., 1994. The metabolic requirement for amino acids in ruminants. In: J.M. Asplund

(Fditor). Principles of protein nutrition of ruminants. CRC Press. Boca Raton, FL, pp. 187-202

Ferrell C.L., 1988. Contribution of visceral organs to animal energy expenditures. J. Anim. Sci 66, Suppl. 3, 23-34

Galloway D.L., Sr., Goetsch A.L., I Iallford D.M., 1996. Effects of supplementing moderate- to low-quality grass hay with maize and(or) rumen undegrdable protein on growth of wethers. Small Ruminant Res. 21, 181-193

Goetsch A.L., Patil A.R., 1997. Relationships among splanchnic tissue energy consumption and net flux of nutrients, feed intake and digestibility in wethers consuming forage-based diets ad libitum. J. Appl. Anim. Res. 11, 1-18

Harris P.M., Lobley G.F., 1991. Amino acid and energy metabolism in peripheral tissues of ruminants. In: T. Tsuda, Y. Sasaki, R. Kawashima (Editors). Physiological aspects of digestion and metabolism in ruminants. Academic Press. New York, NY, pp. 201-230

Ketelaars J.J.M.H., Tolkamp B.J., 1992. Toward a new theory of feed intake regulation in ruminants. 1. Causes of differences in voluntary feed intake: in search of a physiological background. Livest. Prod. Sci. 31, 235-258 
Lobley G.E., 1994. Amino acid and protein metabolism in the whole body and individual tissues of ruminants. In: J.M. Asplund (Editor). Principles of protein nutrition of ruminants. CRC Press. Boca Raton, FL, pp. 147-178

MacRae J.C., Lobley G.E., 1982. Some factors which influence thermal energy losses during the metabolism of ruminants. Livest. Prod. Sci. 9, 447-456

NRC, 1984. Nutrient Requirements of Beef Cattle. 6th Edition. National Academy Press. Washington, DC

NRC, 1985. Nutrient Requirements of Sheep. 6th Edition. National Academy Press. Washington, DC

Ørskov E.R., McDonald I., Fraser C., Corse E.L., 1971. The effect of ad libitum intake of diets varying in protein concentration on performance and on body composition at different weights. J. Agric. Sci., Camb. 77, 351-361

Ørskov E.R., McDonald I., Grubb D.A., Pennie K., 1976. The nutrition of the early weaned lamb. IV. Effects on growth rate, food utilization and body composition of changing from a low to a high protein diet. J. Agric. Sci., Camb. 86, 411-423

Ørskov E.R., Ryle M. (Editors), 1990. Energy Nutrition in Ruminants. Elsevier Applied Science. New York, NY, pp. 28-42

Owens F.N., Gill D.R., Secrist D.S., Coleman S.W., 1995. Review of some aspects of growth and development of feedlot cattle. J. Anim. Sci. 73, 3152-3172

Reynolds C.K., 1992. Metabolism of nitrogenous compounds by ruminant liver. J. Nutr. 122, $850-854$

SAS, 1990. SAS/STAT Users Guide. Version 6, 4th Edition, Volume 2. SAS Institute Inc. Cary, NC Tolkamp B.J., Ketelaars J.J.M.H., 1994. Efficiency of energy metabolism in cattle given food ad libitum: predictions according to the ARC and practical consequences. Anim. Prod. 59, 43-47

Webster A.J.F., 1981. The energetic efficiency of metabolism. Proc. Nutr. Soc. 40, 121-128

\section{STRESZCZENIE}

\section{Rozwój i skład ciała skopków St. Croix, żywionych dawkami różniącymi się zawartością ziarna i poziomem bialka}

Na dwudziestu czterech skopkach $(14,5 \pm 0,53$ kg początkowej masy ciała) oznaczano zdolność zwiększenia wykorzystania paszy poprzez żywienie dawką pokarmową dla rosnących zwierząt ubogą w białko ( $83 \mathrm{dni})$, celem zwiększenia odkładania tłuszczu i częściowego zahamowania odkładania białka, aż do końcowego okresu tuczu trwającego 65 dni, w którym skarmiano dawkę zawierającą $80 \%$ paszy treściwej i $20 \%$ białka ogólnego. W pierwszym okresie doświadczenia ( 83 dni) skopki otrzymały do woli siano z kostrzewy ( $14,4 \%$ białka ogólnego), wolne od endofitów, oraz kukurydzę + mieszankę wysokobiałkową ( $82 \%$ białka og.) w ilości: $1,25 \%$ masy ciała - grupa LM-P, lub 2,5\% masy ciała-grupa HM-P; grupa HM otrzymała siano (j.w.) oraz kukurydzę w ilości 2,5\% masy ciała. Pobranie suchej masy paszy w tym okresie było podobne we wszystkich grupach $(923,978$ i 900 $\mathrm{g} /$ dzień; SE 64,1$)$, a przyrosty jagniąt grupy HM-P były większe $(\mathrm{P} \leqslant 0,05)$ niż z grupy LM-P i HM $(188,139$ i $148 \mathrm{~g} /$ dzień, odpowiednio; SE 8,9$)$. Zawartość białka w masie ciała netto była następująca $(\mathrm{P}<0,5) ; \mathrm{HM}<\mathrm{LP}-\mathrm{P}<\mathrm{HM}-\mathrm{P}(4,10 ; 4,17 ; 4,31 \mathrm{~kg} ; \mathrm{SE} 0,011)$, a zawartość thuszczu była większa $(\mathrm{P}<0,05)$ u jagniąt $\mathrm{z}$ grupy HM-P niż LM-P i HM $(7,01 ; 6,07$ i 5,66 kg, odpowiednio; SE 0,188). Podanie suchej masy oraz przyrosty jagniąt $w$ okresie końcowym oraz skład masy ciała po jego zakończeniu były podobne we wszystkich grupach, chociaż większość różnic w zawartości tłuszczu między grupą HM-P a pozostałymi po pierwszym okresie utrzymała się i w końcowym okresie tuczu (14,2; 13,6 i 13,6 dla grup HM-P, LM-P i HM, odpowiednio; SE 0,80). 